\title{
Developing Flipped Classroom-based Mobile Learning Media to Teach Optical Physics
}

Setya Ferywidyastuti ${ }^{a^{*}}$, Endro Dwi Wuryanto ${ }^{\mathrm{b}}$

${ }^{a}$ Department of Optical Refraction, STIKES HAKLI Semarang, Semarang, Central Java, Indonesia

${ }^{\mathrm{b}}$ Department of Informatics, STMIK Himsya Semarang, Semarang, Central Java, Indonesia

${ }^{*}$ Corresponding author: J1. Stonen Timur No. 25, Gajahmungkur, Semarang, Central Java, 50232, Indonesia. E-mail addresses: setya_ferywidyastuti@yahoo.com

\section{a r t i l e i n f o}

Article history:

Received: 21 October 2020

Received in revised form: 28

November 2020

Accepted: 25 December 2020

Available online: 31 December 2020

Keywords:

Android Apps

Flipped classroom

Mobile learning media

Optical physics

\section{a b s t r a c t}

The application of flipped classrooms-based M-learning media will make learning more planned and systematic. Therefore, students will be more enthusiastic and independent in the learning process. The study aims to design a flipped classrooms-based mobile learning media to teach optical physics and investigate its validity, effectiveness, and practicality. This study employed a research and development method, including defining, designing, developing, and disseminating. Participants in this research were 25 students. Research instruments included expert validation sheets towards learning media developed, a test evaluation of learning results, student response questionnaires, and student activity observation sheets. The expert validation results were analyzed quantitatively and then interpreted to determine the learning media's feasibility. The test and questionnaire results were analyzed in descriptive statistics, while the observation data were analyzed qualitatively. The results reveal that the application of flipped classroom-based Mlearning media in the Optical Physics course is categorized as valid, effective, and practical. Furthermore, the application has a significant effect on student achievements, with a significant difference between the pre-test and post-test. Finally, most students showed positive responses to the application.

\section{Introduction}

One of the latest advanced uses of technology in a learning process is the flipped classroom model. This model is implemented by providing content outside the classroom using technology, and then the activities are carried out in the class (Naccarato \& Karakok, 2015). Educators and researchers from various disciplines are recently focusing on the learning approach of the flipped classroom model (Asiksoy \& Özdamli, 2016) because it positively influences student learning achievement (Leo \& Puzio, 2016; Gross et al., 2015) and increases student involvement in the learning process (Gilboy et al., 2015). The students involved in the flipped classroom model feel more enthusiastic than those in the classical model (Touchton, 2015), and even education students at the Training Teaching School of the University of Extremadura in Spain expect more flipped classroom-based classes (Can et al., 2016). 
The flipped classroom is a learning approach that has been familiar since the existence of learning technology. The flipped classroom is defined as a student-centered active learning approach that aims to increase the effectiveness of a classroom learning process and improve student performances (Asiksoy \& Özdamli, 2016). Moreover, the flipped classroom is an approach that emphasizes a dynamic and interactive learning environment directly involved in the learning process (Mackinnon, 2015). The course contents and materials in the flipped classroom are delivered outside the classroom through technology, and thus, the classroom learning duration focuses on an active learning process (Leo \& Puzio, 2016). Students who are involved in a flipped classroom can find information and learning resources more independently.

One of the technologies that can be integrated into a flipped classroom is digital learning media. The field observations show that the learning media development tends to utilize computers. Consequently, it is less flexible, and the students find it challenging to learn anytime and anywhere. Students in a learning process need accessible and flexible learning media. Based on those criteria, the hardware possibly developed as a learning media is a smartphone with mobile learning applications (Saefi et al., 2017) or Mobile learning media (M-learning media). M-learning media utilizing smartphones is a contemporary and paperless learning media (Taufiq et al., 2016) and gives the students opportunities to access their learning resources anytime and anywhere (Astra et al., 2015).

The use of smartphones, such as M-learning media, attracts many educational researchers because it is portable, accessible, and massively used. M-learning media provides quick access to explore learning resources (Oprea \& Miron, 2014). M-learning media is defined as learning that focuses on technology through mobile devices, such as cell phones, digital audio players, digital cameras and voice recorders, pen scanners, etc. (Keskin \& Metcalf, 2011). Mobile learning media related to students' mobility aims to facilitate their learning without the time and location constraints; thus, it can encourage and improve communication and interaction among students (Astra et al., 2015; Mahmoud et al., 2015). M-learning media benefits can make a class more interactive, it allows the learning process to continue after the class ends, and students will learn more independently (Zydney \& Warner, 2016).

The application of M-learning media in physics learning using a smartphone can encourage physics teachers more creative and innovative in presenting instructional materials (Simanjuntak \& Budi, 2018). Furthermore, M-learning media is proven to have very positive 
influences to engage students in learning physics (González et al., 2015). Another benefit of M-learning media using a smartphone is an experimental tool in explaining materials that are necessarily visualized (Mardiana \& Kuswanto, 2017; Oprea \& Miron, 2014). Besides, smartphones used in M-learning media can transform the learning experiences and then direct students to develop their thinking skills, analysis, and learning plans (Mardiana \& Kuswanto, 2017). The previously mentioned literature concludes that learning physics using smartphonebased learning media can encourage students to be more active and critical in the learning process.

The M-learning media research developed in this research is an Android-based interactive learning application. Android-based learning can be used as an alternative interactive learning media to motivate students to learn independently (Simanjuntak \& Budi, 2018). It can improve critical thinking patterns in learning physics (Mardiana \& Kuswanto, 2017). The combination of M-learning media and flipped classroom potentially create a better learning experience in teaching physics. From the studies mentioned earlier, M-learning media has been prevalent in learning physics, but few studies concern specific parts of physics, such as optical physics.

Optical physics is a part of physics that focuses on investigating the basics of light, and its interactions towards the material, including classical optical phenomena such as reflection, etc. Optical physics learning is a compulsory subject in the Diploma Program of Optic Refraction Department at STIKES HAKLI Semarang. This subject is complicated for the students to understand, and they are not active in the learning process. M-learning media was implemented to overcome these problems by designing an installable mobile learning application on students' smartphones to learn the subjects everywhere and more independently. The M-Learning media for optical physics were designed and developed in this study based on specific characteristics, i.e., the students can access materials and exercises offline or without an internet connection. Therefore, they can quickly learn and practice the materials. The key answers and explanations were given after the students had completed the exercises to provide a fast evaluation. The learning assessment was connected to the internet, and thus, the lecturers could monitor and evaluate the students' comprehension of learning materials.

Finally, this study aims to design a flipped classrooms-based mobile learning media to teach optical physics and investigate its validity, effectiveness, and practicality. The validity 
was explored based on the product descriptions of developed flipped classroom-based Mlearning media. The effectiveness was measured by implementing a flipped classroom-based M-learning media in teaching optical physics to enhance students' learning achievement based on their learning and classroom activities. Meanwhile, practicality was investigated from the students' perceptions after implementing flipped classroom-based M-learning media to master optical physics.

\section{Method}

This research participants were 25 students in semester 1 of Academic Year 2020-2021 in the Diploma Program of Optic Refraction Department STIKES HAKLI Semarang. This research's independent variable was the application of flipped classroom-based M-learning media, while the dependent variable was student learning outcomes in the Optical Physics course. The research topics developed included light, light waves, light dispersion, light interference, light diffraction, and light polarization.

The flipped classroom learning stages (Brame, 2019a) were adapted and implemented in the M-learning media application before, during, and after the learning. In the before learning stage of teaching optical physics, the lecturer prepared optical physics materials and exercises. Afterward, he allowed the students to prepare themselves in meaningful and productive ways. Consequently, they read and understood new concepts and terminology related to the learning topics through an Android mobile application without an internet connection because the materials and exercises had been installed in the application. They took notes and wrote down questions to discuss different topics in the classroom.

During the learning process, the lecturer organized activities focusing on higher-level cognitive function and helped students receive input knowledge from peers and their teachers to achieve the learning goals. Learning activities were conducted by exploring students' comprehension after they had practiced the exercises using mobile applications. These activities involved peer discussions and interaction with the lecturer.

Students continued their activities to evaluate the learning through a test by using a mobile application connected to the internet in the after learning stage. Thus, the lecturer could monitor and evaluate the students' comprehension of learning materials. It was conducted to provide opportunities for students to strengthen and broaden their knowledge. 
This research employed a research and development method, and its stages included planning, designing, developing, and disseminating. They aimed to develop M-learning media (Android application) to learn optical physics based on the flipped classroom. The planning was done by analyzing the initial analysis, students, concepts, assignments, and learning objectives from optical physics. The initial stage was conducted by reviewing the literature, teaching materials, and learning methods in line with the learning trends.

The student analysis stages were conducted by assessing students, including their backgrounds, learning styles, and learning motivation to constitute the selection of learning topics and language used, and by adjusting the student's cognitive development. The concept analysis stage was to identify topics that met the students' needs, and thus, the analysis was systematically arranged. The task analysis stage aimed to compile tasks under the procedure, and then the material outline was compiled in M-learning media. Formulating the learning objectives was conducted after the analysis concepts and tasks had been available. It aimed to create learning objectives and indicators to achieve.

The designing stages included making the M-learning media (Android application) for the optical physics course and designing the research instruments. This stage product was draft 1 of the M-learning media, test, and questionnaire. At this stage, the activities included validating the developed learning media and testing the M-learning media on a limited and large scale. Two experts at learning content and learning media conducted the validation. Expert validation validated learning material contents by a content expert and media appearance and practicality by a learning media expert. The initial validated design was then tried out in a small group of 10 students. Each student installed the learning media on their smartphone. The purpose of the limited scale test was to determine the legibility and clarity of the material and the tasks integrated with the Android-based optical physics learning media application.

The next stage was revising the limited-scale trial results to produce a learning media design concept that was readily tested on a large scale. The broad-scale trial implemented the flipped classroom approach. The broad-scale trial participants were 25 students of semester 1 in the diploma program of the Optical Refraction Department at STIKES HAKLI Semarang. The results of the broad-scale trial were then revised to produce the final results of learning media. This final stage aimed to revise the M-learning media design based on the experts' inputs and data obtained from the limited and large-scale trials. 
The dissemination stage of development research included obtaining the copyright on the interactive learning application for the flipped classroom-based M-learning media (Android application). The research process and results were reported and published in a scientific article.

The research data collected based on four instruments: expert validation sheets, test, questionnaire, and observation. The expert validation was administered in developing $\mathrm{M}$ learning media, and the questionnaire was used to discover the students' responses to the practicality of using the learning media. Meanwhile, student activities were observed by using observation sheets during the learning process.

The expert validation sheet results were analyzed quantitatively and then interpreted to determine the feasibility of developed M-learning media. The analysis of test results and student responses was taken from the broad-scale trial results and used descriptive statistics of SPSS 21. Meanwhile, the observation data were analyzed by descriptive qualitative method. Data analysis of the instruments could provide a compulsorily comprehensive description (Sung et al., 2016) that would be implied for the use of instructional media theory.

\section{Results and Discussion}

These research results are elaborated based on research product description, validation results, effectiveness, and practicality of flipped classroom-based M-learning media to teach optical physics.

\section{Research product description}

This study developed a product in the learning media converted into an Android Package (apk.). The application is sendable to the students via Bluetooth transfer, Whatsapp sharing, or email. The product designs consist of the menu page, teaching materials page (light $\&$ its properties, light waves, light deficiency, light interference, light diffraction, and light polarization), training page for each material, evaluation page, and evaluation history page. These designs are presented in Figure 1. The teaching material page consists of the materials taught and the exercise menu, as illustrated in Figure 2. The available materials and exercises can be accessed offline and independently, and thus, the students can still learn the materials without an internet connection. 


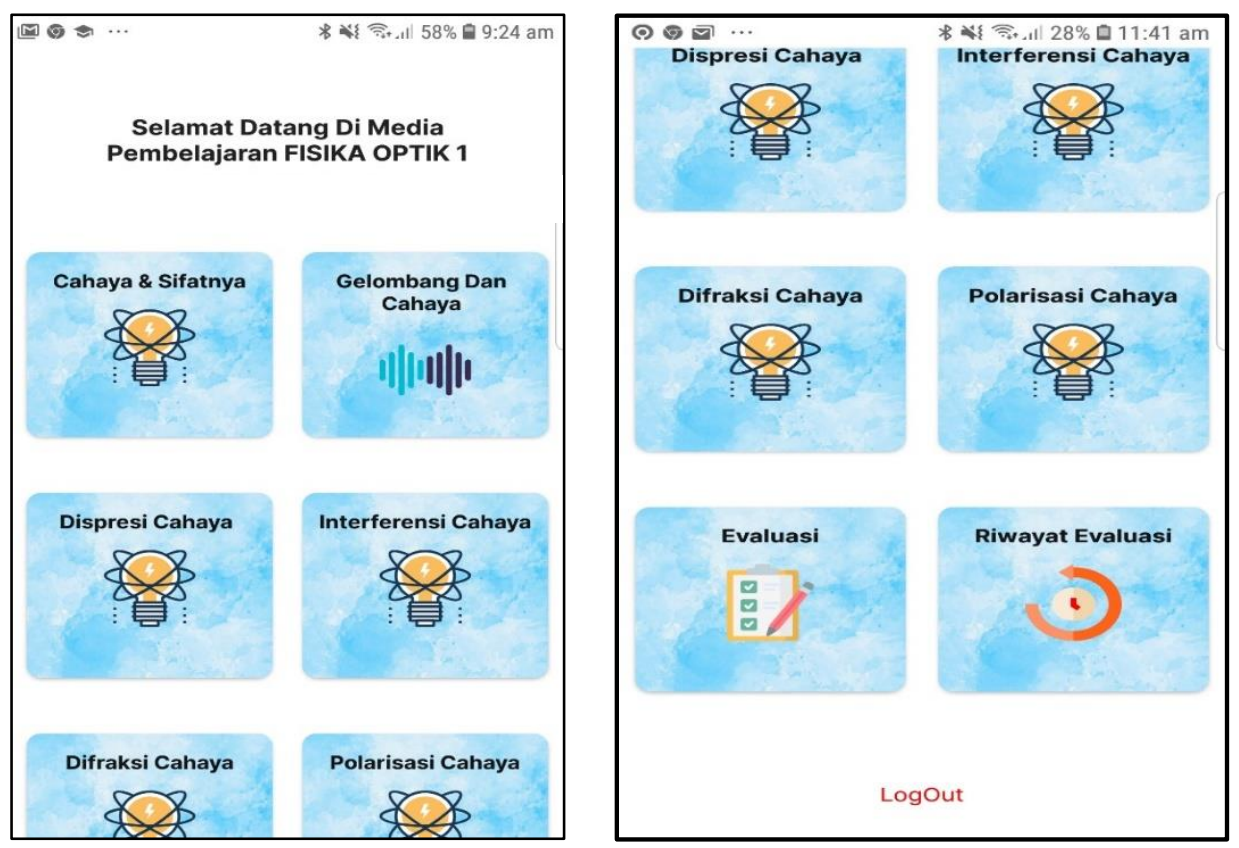

Figure 1. Main menu page
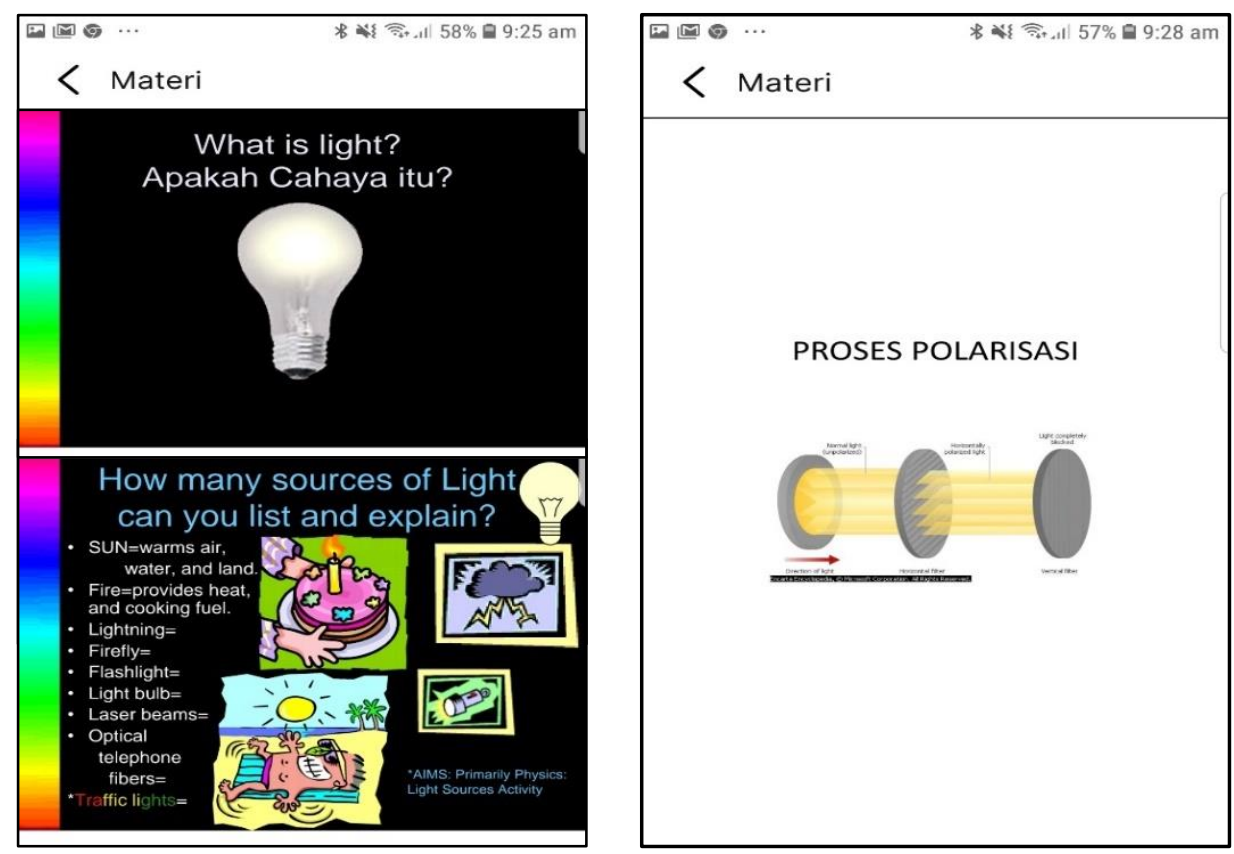

Figure 2. Examples of teaching material pages

It is expected that the design of the exercises with answer keys can encourage students to learn independently and involve more interactively. The answer key will appear after they complete the task. The task of each material is presented in Figure 3. 


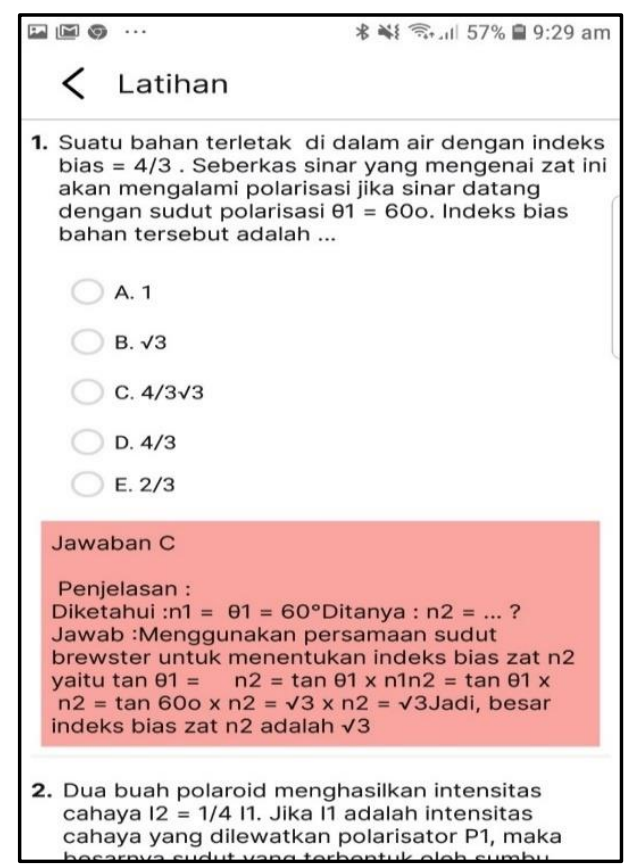

\begin{tabular}{|c|}
\hline $\begin{array}{l}\text { Latihan } \\
<\quad \text { La }\end{array}$ \\
\hline $\begin{array}{l}\text { 1. apa itu cahaya? } \\
\text { Jawaban di tulis di buku kalian }\end{array}$ \\
\hline $\begin{array}{l}\text { 2. Sebut dan Jelaskan sumber cahaya! } \\
\text { Jawaban di tulis di buku kalian }\end{array}$ \\
\hline $\begin{array}{l}\text { 3. Sebut dan jelaskan sifat-sifat cahaya, serta } \\
\text { masing-masing berikan contohnya dalam } \\
\text { kehidupan sehari-hari! } \\
\text { Jawaban di tulis di buku kalian }\end{array}$ \\
\hline $\begin{array}{l}\text { 4. Jelaskan proses terjadinya pelangi ! } \\
\text { Jawaban di tulis di buku kalian }\end{array}$ \\
\hline $\begin{array}{l}\text { 5. Deskripsikan rancangan percobaan sederhana } \\
\text { dengan menggunakan peralatan yang ada di } \\
\text { sekitar kita untuk membuktikan sifat-sifat } \\
\text { cahaya (tentukan } 1 \text { (satu) sifat cahaya). } \\
\text { Rancangan percobaan memuat tujuan, alat dan } \\
\text { bahan, prosedur serta kesimpulan! } \\
\text { Jawaban di tulis di buku kalian }\end{array}$ \\
\hline Kirim Jawaban \\
\hline
\end{tabular}

Figure 3. Examples of an independent practice page with an answer key after the students' work accomplishment

The evaluation page presented in Figure 4 consists of questions designed to determine the students' level of ability after they understand each material taught. This evaluation page is presented online, and thus the teacher can get the students' scores that will be connected to the lecturer's application.

\begin{tabular}{|l}
\hline Evaluasi \\
1. Sir Issac Newton menyatakan bahwa cahaya \\
merupakan ... \\
A. gelombang elektromagnetik \\
B. gelombang longitudinal \\
c. gelombang tranversal \\
D. gelombang mekanik \\
2. IImuwan yang berseberangan pendapat dengan \\
Newton mengenai hakikat cahaya pada masa itu \\
adalah.... \\
A. Fresnel \\
B. Max Planck \\
c. Albert Einsten \\
D. Stephen Hawking \\
3. Teori dualisme cahaya yaitu sebagai gelombang \\
dan sebagai partikel dikemukakan oleh ... \\
A. Newton
\end{tabular}

Figure 4. Evaluatable-online evaluation page by the lecturers 


\section{Validation results}

After designing and developing the Android-based M-learning media, this study validated the application by two experts at teaching science and teaching multimedia learning. The validation process was conducted at the design stage of this development research. The expert assessment was implemented based on the validators' assessment sheets. The expert validation on flipped classrooms-based M-learning Android media reveals a recapitulation score by 31 ; the score is categorized good and declared a valid result. The recapitulation of the flipped classroom-based M-learning assessment score for Android media is presented in Table 1, and the interval for M-learning media evaluation is presented in Table 2.

Table 1. Recapitulation of the assessment score for M-learning media

\begin{tabular}{ccccccc}
\hline \multirow{2}{*}{ Component } & \multicolumn{2}{c}{ Validator } & Average & $\begin{array}{c}\text { Max } \\
\text { Score }\end{array}$ & Information \\
\cline { 2 - 4 } & $\mathbf{1}$ & $\mathbf{2}$ & & 30 & 40 & M-learning media is usable \\
Content (content) & 30 & 30 & 30 & 31 & 40 & with minimal revision and \\
Language & 32 & 33 & 32 & 40 & valid status \\
Display & 31 & 31 & & \\
& Total & & & &
\end{tabular}

Table 2. Assessment interval of M-learning media

\begin{tabular}{ccc}
\hline Score & Score & Information \\
\hline $33 \leq \mathrm{n} \leq 40$ & Very good & It is usable without revision and valid \\
$26 \leq \mathrm{n} \leq 32$ & Well & It is usable with minimal revisions and valid \\
$18 \leq \mathrm{n} \leq 25$ & Pretty good & It is usable but requires many revisions \\
$10 \leq \mathrm{n} \leq 17$ & Not good & It not is usable and still requires revisions and consultation \\
\hline
\end{tabular}

The data in Table 1 show that M-learning media has been developed in the 'Good' category. These categories conclude that M-learning media is usable with some revisions. The validators' revisions:

a. The discussion in the answer key page must be presented structurally to facilitate students' read.

b. The exercise questions, along with their answer keys, appear after the students have completed all the exercises.

c. Based on these revisions, this study requires rearranging the answer keys of each exercise in each topic. As a result, students can do the exercises immediately after reading and understanding the material. Each answer key from these exercises is displayed after they complete the task. 
After the learning media was revised based on the validators' suggestions, the Androidbased M-learning media determined its effectiveness and practicality. The effectivity was tested in 25 diploma students of the Optisi Refraction Department in flipped classroom learning. The technology-based learning media was integrated to create student-centered learning in every meeting. The practicality was analyzed based on the students' responses after they had completed the learning activities available in the developed learning media.

\section{Effectiveness of M-learning media}

The results of M-learning media effectiveness in the flipped classroom include 1) analysis of student learning outcome tests and 2) observation of student activities. The analysis results of the learning test were given before and after the students had attended the learning activities. The results of students' learning tests are presented in Table 3.

Table 3. Descriptive statistics of students' learning results

\begin{tabular}{cccccc}
\hline & N & Minimum & Maximum & Mean & Std. Deviation \\
\hline Pre-test & 25 & 60.00 & 88 & 75 & 8.56349 \\
Post-test & 25 & 62.00 & 98 & 89 & 11.92099 \\
Valid N (listwise) & 25 & & & & \\
\hline
\end{tabular}

The descriptive statistical analysis results show that the students' learning outcomes in the optical physics course increase 14 points, from 75 in the pre-test to 89 in the post-test. It indicates that the use of flipped classroom-based Android learning media significantly influences student achievement. The paired sample test proves this considerable effect and indicates that the p-value is below 0.05 . These results are presented in Table 4.

Table 4. Results of the paired sample test in pre-test and post-test

Paired Samples Test

\begin{tabular}{cccc}
\hline & T & Df & Sig. (2-tailed) \\
\hline Pre-test - Post-test & -6.998 & 24 & .000 \\
\hline
\end{tabular}

Furthermore, the students' activities during learning using flipped classroom-based Mlearning media were observed using observation sheets. Three observers, consisting of the researcher and two observers, collected student activity data through the observation. The interval criteria for the students' scores are presented in Table 5.

$\underline{\text { Table 5. Interval score criteria of student activity assessment }}$

\begin{tabular}{cc}
\hline Interval & Criteria \\
\hline $3.3 \leq \mathrm{n} \leq 4$ & Very active \\
$2.6 \leq \mathrm{n} \leq 3,2$ & Active \\
$1.8 \leq \mathrm{n} \leq 2.5$ & Quite active \\
$1 \leq \mathrm{n} \leq 1.7$ & Not active \\
\hline
\end{tabular}


The observation result analysis of student activity reveals that the average score of students' activity on learning optical physics devices is 3.5. This result is categorized as very active and shows that the students more enthusiastically learned with M-learning media because they could learn more independently and flexibly with their cellphones. Furthermore, this result agrees with previous studies deploying that technology-based learning via mobile phones much supports student learning activities because technology-based learning media can increase the students' learning interests and the effectiveness of the learning process (Sung et al., 2016; Muyaroah \& Fajartia, 2017). It can be summarized that students more easily understand the materials because M-learning media can make the teaching and learning process enjoyable, and the students are highly interested in the process.

\section{The practicality of M-learning media}

The analysis of students' responses shows that $85 \%$ of them responded positively. Moreover, they stated that learning optical physics by using the Android application in the flipped classroom motivated them to learn, and they were enthusiastic during the learning process. These results indicate that the flipped classrooms-based M-learning Android media developed in this research was categorized as a practical application. The previous study supports this finding that flipped classrooms can facilitate students to have an interactivevirtual tool outside the classroom and the valuable-active learning approaches (Brame, 2019a).

The practicality indicators in using flipped classroom-based M-learning media are the students' great activity and responsibility in the learning process. M-learning media provides opportunities for the students to express their opinions and respect others' opinions

successfully, students' better-learning results, and opportunities for every student to actively be involved in discussions. Furthermore, a study by (Vieyra et al., 2015) corroborated that Mlearning media helped teachers integrate the technology in the classroom better and improved learning outcomes and student engagement.

\section{Conclusion}

The application of flipped classroom-based M-learning media in the optical physics course is valid, effective, and practical. The expert validation shows that the M-learning media is categorized as valid and is possibly implemented in learning. Moreover, the use of M-learning media has a significant effect on student achievement. The considerable differences between 
the pre-test and post-test declare that M-learning media is effective in the classroom. Meanwhile, the effectiveness of M-learning media is proven by the student activities observed during the learning process using the observation sheets. Practicality is proven from the questionnaire results. The majority of students responded positively and argued that learning optical physics by applying the flipped classroom-based M-learning media could motivate them to master the course enthusiastically and enjoyed the learning process.

\section{Acknowledgements}

The authors are very grateful to the Ministry of Research, Technology, and Higher Education of the Republic of Indonesia who financially supported the establishment of this study.

\section{References}

Asiksoy, G., \& Özdamli, F. (2016). Flipped classroom adapted to the ARCS model of motivation and applied to a physics course. Eurasia Journal of Mathematics, Science and Technology Education, 12(6), 1589-1603. https://doi.org/10.12973/eurasia.2016.1251a

Astra, I. M., Nasbey, H., \& Nugraha, A. (2015). Development of an Android application in the form of a simulation lab as learning media for senior high school students. EURASIA Journal of Mathematics, Science and Technology Education, 11(5), 1081-1088. https://doi.org/10.12973/eurasia.2015.1376a

Brame, C. J. (2019a). Chapter 9 - Flipping the Classroom. In C. J. B. T.-S. T. E. Brame (Ed.) (pp. 121-132), Academic Press https://doi.org/https://doi.org/10.1016/B978-0-12-8147023.00009-3.

Can, F., Jeong, J. S., \& Gonza, D. (2016). Students' perceptions and emotions toward learning in a flipped general science classroom. Journal of Science Education and Technology, 25(5), 747-758. https://doi.org/10.1007/s10956-016-9630-8

Gilboy, M. B., Heinerichs, S., \& Pazzaglia, G. (2015). Enhancing student engagement using the flipped classroom. Journal of Nutrition Education and Behavior, 47(1), 109-114. https://doi.org/10.1016/j.jneb.2014.08.008

González, M., González, M., Martín, M. E., Llamas, C., Martínez, Ó., Vegas, J., Herguedas, M., \& Hernández, C. (2015). Teaching and learning physics with smartphones. Journal of Cases on Information Technology, 17(1), 31-50. https://doi.org/10.4018/JCIT.2015010103

Gross, D., Pietri, E. S., Anderson, G., Moyano-camihort, K., \& Graham, M. J. (2015). increased preclass preparation underlies student outcome improvement in the flipped classroom. CBE-Life Sciences Education, 14(4), 1-8. https://doi.org/10.1187/cbe.15-020040.

Keskin, N. O., \& Metcalf, D. (2011). The current perspectives, theories, and practices of mobile learning. Turkish Online Journal of Educational Technology-TOJET, 10(2), 202208. 
Leo, J., \& Puzio, K. (2016). Flipped instruction in a high school science classroom. Journal of Science Education and Technology, 25(5), 775-781. https://doi.org/10.1007/s10956-0169634-4

Mackinnon, G. (2015). Determining useful tools for the flipped science education classroom. Contemporary Issues in Technology and Teacher Education, 15(1), 44-55.

Mahmoud, S. T., Alshannag, Q., \& Malkawi, E. (2015). Exploring the impact of iPads in teaching introductory physics courses at UAEU. The International Academic Forum, December, 1-10.

Mardiana, N., \& Kuswanto, H. (2017). Android-assisted physics mobile learning to improve senior high school students' divergent thinking skills and physics HOTS. AIP Conference Proceedings, 1868(August), 070005. https://doi.org/10.1063/1.4995181

Muyaroah, S., \& Fajartia, M. (2017). Pengembangan media pembelajaran berbasis Android dengan menggunakan aplikasi Adobe Flash CS 6 pada mata pelajaran biologi. Innovative Journal of Curriculum and Educational Technology, 6(2), 22-26. https://doi.org/10.15294/ijcet.v6i2.19336

Naccarato, E., \& Karakok, G. (2015). Expectations and implementations of the flipped classroom model in undergraduate mathematics courses. International Journal of Mathematical Education in Science and Technology, 46(7), 968-978. https://doi.org/10.1080/0020739X.2015.1071440

Oprea, M., \& Miron, C. (2014). Mobile phones in the modern teaching of physics. Romanian Reports in Physics, 66(4), 1236-1252.

Saefi, M., Lukiati, B., \& Suarsini, E. (2017). Students' cognitive comprehension. Jurnal Pendidikan Sains, 5(2), 57-63.

Simanjuntak, B. R., \& Budi, E. (2018). The development of web-based instructional media for teaching wave physics on Android Mobile. Jurnal Penelitian \& Pengembangan Pendidikan Fisika, 4(1), 1-10. https://doi.org/10.21009/1.04101

Sung, Y. T., Chang, K. E., \& Liu, T. C. (2016). The effects of integrating mobile devices with teaching and learning on students' learning performance: A meta-analysis and research synthesis. Computers and Education, 94(November), 252-275. https://doi.org/10.1016/j.compedu.2015.11.008

Taufiq, M., Amalia, A. V., Parmin, P., \& Leviana, A. (2016). Design of science mobile learning of eclipse phenomena with conservation insight Android-based app inventor 2 . Jurnal Pendidikan IPA Indonesia, 5(2), 291-298. https://doi.org/10.15294/jpii.v5i2.7375

Touchton, M. (2015). Flipping the classroom and student performance in advanced statistics: Evidence from a quasi-experiment. Journal of Political Science Education, 11(1), 28-44. https://doi.org/10.1080/15512169.2014.985105

Vieyra, R., Vieyra, C., Jeanjacquot, P., Marti, A., \& Monteiro, M. (2015). Turn your smartphone into a science laboratory. The science teacher, 82(9), 32-40. https://doi.org/10.2505/4/tst15

Zydney, J. M., \& Warner, Z. (2016). Mobile Apps for science learning: Review of research. Computers and Education, 94, 1-17. https://doi.org/10.1016/j.compedu.2015.11.001 